\title{
WINIFRED MARY CURTIS: A BIOGRAPHICAL SKETCH
}

\author{
by Gintaras Kantvilas
}

(with one plate and an appendix)

\begin{abstract}
Winifred Mary Curtis was born in England and, pursuing an early interest in science, graduated from University College, London. While teaching in England she carried out botanical research leading to a MSc degree before emigrating to Tasmania in 1939. Here she taught, wrote and lectured, while conducting research which led to $\mathrm{PhD}$ and DSc degrees, and also becarne involved in two major projects, The Students Flora of Tasmania and The Endemic Flora of Tasmania. (Ed.)
\end{abstract}

Key Words: Winifred Mary Curtis, Tasmanian flora.

In BANKS, M.R. et al. (Eds), 1991 (31:iii): ASPECTS OF TASMANIAN BOTANY - A TRIBUTE TO WINIFRED CURTIS. Roy. Soc. Tasm. Hobart: 1-6. https://doi.org/10.26749/rstpp.124.2.1

Winifred Mary Curtis was born on 15 June 1905 in London, England, the only child of Herbert John Curtis and Elizabeth Winifred Curtis (née Baker), both of Poole, Dorset. While Winifred was still a child, the family moved from the suburb, Charlton, to live at the top of Shooters Hill, then a semi-rural district. John Curtis was a civil servant employed in the War Office, in the branch responsible for the design, specification and inspection of all army equipment made from wood. He was not only knowledgeable about timbers but also keenly interested in living trees. From an early age, Winifred was encouraged to learn about the plants in her own small garden and the rees in the surrounding fields, and to use the books on the well-filled bookshelves. Winifred always pays tribute toher parents who, during the early years of this century, were in the vanguard of those believing that girls should have the same educational advantages as boys, and who gave her every opportunity to study as she wished.

In 1914, the First World War ended the rural quiet of the family and of Shooters Hill. An anti-aircraft gun was stationed in the field adjoining the Curtis' house and the gunners were alerted every time a Zeppelin crossed the English Channel. Before long, John Curtis was seconded to the British Army and commissioned in the General Division for duty in India in liaison with the newly formed Inspection Division of the Indian Army. Winifred and her mother moved to live with her father's married sister and her family at Newport on the Isle of Wight, and later to Boumemouth near her maternal grandparents. It was not until the New Year of 1920 , when Winifred was 14 , that the family was reunited in India. John Curtis was stationed at Cawnpore (Kanpur), on the banks of the river Ganges in the United Provinces (Uttar Pradesh). Winifred spent two happy school years at a girls boarding school at Naini Tal, about two days travel away at an altitude of over $2000 \mathrm{~m}$ in the foothills of the Himalayas. The school was American, staffed from Wellesley College, and had been established primarily for the daughters of American medical missionaries, although its complement of about 120 children was cosmopolitan. The 1920's saw unsettled times in India, with hartals and demonstrations against the British raj, but it was with reluctance that the family obeyed the recall to London in the autumn of 1921. For Winifred this was the fifth change of school.

In 1924, Winifred enrolled at University College, London, to study botany, chemistry, mathematics and physics. Maths was not her forté but class prizes in botany, chemistry and physics provided textbooks in these subjects for the following year. In 1926, she again won the class prize in botany and, in an open competitive examination, the London University Scholarship in Botany, a sum of $£ 80$ which almost covered the annual college fee. She graduated in 1927 with a BSc General degree in botany, chemistry and physics, and was awarded the Gold Medal and Sarah Baker-Ellen Richards Prize for Botany. Winifred was granted the Catherine Maud Pearce Postgraduate Scholarship for women and enrolled for an honours degree in botany.

The Botany Department of University College was a friendly and stimulating workplace with a long tradition of excellence. The college was founded in 1827 as the University of London and lectures were inaugurated in the following year. The first Professor of Botany had been John Lindley, who was followed by Daniel Oliver, Keeper of the Herbarium of the Royal Botanic Gardens, Kew. He was succeeded by his son, Francis W. Oliver, a renowned palaeobotanist, who held the chair during Winifred's time. Former distinguished members of staff included the pioneer plant ecologist, Sir Arthur Tansley, and the algologist, F.E. Fritsch. Current staff included T.G. Hill and P. Haas, co-authors of the text Introduction to the Chemistry of Plant Products, and the ecologist, E.J. Salisbury, who later became Director of the Royal 
Botanic Gardens, Kew. Intercollegiate lectures were a feature of the university and those of Professor Dame Helen Gwynne-Vaughan of Birbeck College left an indelible memory. These were also the early days of the British Ecological Society, when 30-40 members met regularly in the Botany Department of the college. Winifred became a keen member, obtaining great pleasure and benefit from meetings and excursions. Later she was granted Honorary Life Membership of the Society.

For her honours degree, Winifred began research under the direction of Professor F.W. Oliver on the origin and status of a grass then known as Spartina townsendii. Plants of this grass had been first collected in southern England in 1870, on the muddy margins of Southampton Water, and again in 1892, at Lymington, Hampshire. The species spread rapidly from these localities to cover thousands of acres of tidal mud flats of southern and southeastern England.

Winifred obtained her BSc Honours degree in botany in 1928 but remained in the department as an Honorary Demonstrator, a position she enjoyed greatly and one which offered excellent teaching experience. However, by 1930 , she realised that a permanent appointment in botany could not be found. During the 1914-18 war, women had been appointed, albeit reluctantly, to positions in industry, research and the civil service, but in the years of the depression, a reaction against such appointments prevailed. She therefore enrolled at the Cambridge Teachers College and, in 193 I, obtained the Cambridge Teachers Certificate. She was appointed Senior Science Mistress at the newly established Levenshulme Girls High School in Manchester. During evenings and weekends, Winifred continued her research on Spartina in the basement of the Botany Department of the University of Manchester. From plants collected at Poole, she obtained evidence of successful pollination and growth of the pollen tube through the micropyle into the embryo sac.

In January 1933, Winifred moved back to London to an appointment as Biology Specialist at South Hampstead High School, one of the earliest schools in England established to provide secondary education for girls, which was founded by the Girls' Public Day School Company in 1876 . It was a happy school, maintaining a high academic standard and reputation. In London again, she was able to accept an invitation from Dr W.B. Turrill, Keeper of the Herbarium at Kew, to carry out research under his direction. She published the results of her work on the floral morphology of Spartina and began a study of some apomicts of Taraxacum (dandelions). The latter work was terminated in 1939 and accepted for a MSc degree.

Winifred's father retired in 1938. In the following year, he was able to carry out his plan, envisaged while in India, of retirement in a part of the British Empire having a milder climate than that of England. His preferences were New Zealand, Tasmania and Vancouver, and Winifred wrote to universities in these places for possible employment. The most promising reply, although lacking any job offer, came from Dr V.V. Hickman, Head of the Biology Department at the University of Tasmania, and so the decision to come to Tasmania was made.

The family arrived and settled in Hobart in September 1939 , after a voyage of about six weeks. Winifred very soon obtained a part-time appointment as Demonstrator and Research Scholar in the Biology Department of the university. This position made her only the second woman to be appointed to the academic staff of the university, and the only one serving at that time. She worked under the direction of Dr Hickman, an outstanding zoologist and later, when a Chair was established, Ralston Professor of Biology. Botany had only recently been accepted as a subject in the BSc degree of the university and was taught by Dr H. D. Gordon, an Edinburgh graduate with interests in fungi and green algae.

In October 1939, Winifred also obtained a part-time appointment as Science Mistress at Fahan, a private girls school established four years previously. She initiated the teaching of elementary science and prepared classes for the School Certificate and Higher School Certificate examinations in biology. She found it frustrating to use textbooks that described only British plants and animals, and therefore wrote a text at School Certificate level, Biology for Australian Students. Published in 1948, with three revised editions to 1962 , the book served a generation of students. Ironically, she never taught from it herself, having abandoned schoolteaching by the time it was published.

During the Second World War, there was concern in Tasmania that the island could be invaded by the Japanese for use as a base. In 1942, to escape any such attack, Fahan School was evacuated to Interlaken on the Central Plateau. Winifred commuted every few weeks between school and university, with brief detours to National Park where her parents had rented accommodation. The journeys were adventurous because the wheelbase of the small family car was not wide enough to fit the ruts of the unmade roads.

During the last term of 1942, Winifred was offered and accepted a full-time appointment as Assistant Lecturer in Biology at the university. When the disciplines of botany and zoology were separated in 1945, she was appointed Lecturer in Botany. Her later appointments in the department were Senior Lecturer (1951) and Reader (1956). Her botanical research in Tasmania began with a study of chromosome numbers in the lily Dianella and in certain shrubby legumes. 
Shrubs of Prickly Beauty (Pultenaea juniperina) proved to be diploid $(2 n=18)$ and tetraploid $(2 n=36)$ while stands of morphologically distinct plants, sterile and reproducing vegetatively, were found to be triploid. Published in 1944, this was the first record of polyploidy in Australian native plants. The work was incorporated in a thesis for a London $\mathrm{PhD}$ degree, conferred in 1950.

The teaching load in botany, divided between Dr Gordon and Winifred, was heavy. The native flora was quite unfamiliar to them, although Winifred had had limited exposure to some Tasmanian species as a botany student in England. However, in 1943, when a telephone call from the Govemment Printer offered them an opportunity to revise Rodway's out-of-print Tasmanian Flora, the offer was at once accepted. They did not foresee that the work would involve writing a completely new Flora and would take more than 40 years to complete.

For use in teaching, the two botanists themselves collected the plants needed, confirming their identifications by comparison with specimens in the Tasmanian Museum Herbarium. This herbarium, incorporating several important historical collections, was established by Leonard Rodway in 1928. After his death in 1936, the Herbarium remained in the care of his widow, Olive Rodway, who was generous with her help. She gave up this work in 1941, and the only attention that could then be afforded for the collections was that provided by Winifred as part-time Keeper on Saturday afternoons. By this time, the herbarium had been moved to a wooden hut in the Botanical Gardens, due to lack of space in the museum. In 1946, the trustees of the museum agreed to a request by Dr Gordon for the herbarium to be moved to the university as a permanent loan under the care of the Head of the Botany Department, thus establishing the link between these institutions that still remains. No special staff or help was provided and the work became an unofficial addition to Winifred's duties, leading her to become a staunch supporter of the herbarium and to argue strongly for its due recognition and needs.

By 1947, there was a considerable increase in the number of university students due to an influx of ex-servicemen. Classes had to be duplicated because of a shortage of laboratory equipment. That year, Dr Gordon resigned to take the Chair of Botany at the Victoria University in Wellington, New Zealand. Winifred became responsible, with the assistance of Mary Cameron, a recent graduate, for all the teaching and for running the department, pending the appointment of Dr H.N. Barber to the newly-established Chair of Botany. This period as Acting Head of Department was the first of several during the next two decades.

Writing for the new Tasmanian Flora had scarcely begun when Winifred became solely responsible for the project. Flora writing was generally done in the evenings, after class matters had been attended to, for although an additional lecturer was appointed to the Botany Department, teaching remained a full-time commitment. Winifred learnt to type and prepared the manuscript herself. The university had moved to its present site at Sandy Bay in the late 1940's, and the Departments of Botany and Zoology occupied temporary huts on the lower campus. The herbarium occupied a separate draughty hut nearby and was her workplace. Gradually The Students Flora of Tasmania took shape, the families described according to the system of Bentham and Hooker and published when a sufficient number was completed to comprise a volume. Part 1 (to Myrtaceae) was published in 1956, followed by Part 2 (to Epacridaceae) in 1963, Part 3 (to Salicaceae) in 1967, and Part 4a (Orchidaceae) in 1980. With few exceptions, descriptions were written from fresh material collected during vacations by Winifred, accompanied, for the first two volumes, by Miss Janet Somerville, a gifted naturalist and one of the first group of Tasmanian science graduates to include botany in their BSc degrees. Collecting sites were reached by bus, much walking on unmade roads, and use of primitive camping huts in national parks.

After 1950, travel to the mainland and overseas, which had previously been curtailed by post-war shortages and lack of staff at the university, again became practicable. Winifred had always liked travel, particularly by sea, and tended to select voyages with more interesting itineraries and stopovers. During vacations, she studied for short periods in the herbaria in Melbourne and Sydney, meeting colleagues there and being encouraged and helped by them. She also revisited and studied at Kew, attended the VII International Botanical Congress in Stockholm (1950) and the IX Congress in Montreal (1954). The journey to Montreal and to selected university botany departments in the USA was made possible in 1959 by the award of a Travel Grant from the Carnegie Corporation of New York. She also attended the ANZAAS Conference in New Zealand in 1957. These visits led to her continuing friendship and correspondence with botanists throughout the world.

In the early 1960's, during a botanical excursion arranged for visitors to Hobart, Winifred rnet Dennis Morris from the State Department of Agriculture. They soon discovered that they shared a keen interest in the local flora and agreed to collaborate on the unfinished Students Flora. Since that time they have revised Part 1 and are progressing towards the end of the final Part $4 \mathrm{~b}$.

Work on the Students Flora was interrupted by Winifred's involvement with preparation of The Endemic Flora of Tasmania, a six-volume book of text and paintings of Tasmania's endemic vascular plants 
published between 1967 and 1978. The project was conceived and sponsored by Lord Talbot de Malahide, retired from the British Diplomatic Service. Lord Talbot was an avid collector and gardener who cultivated Tasmanian plants on his estate in Ireland. $\mathrm{He}$ commissioned Margaret Stones, an Australian botanical artist employed at Kew, to undertake a series of paintings of Tasmanian endemic plants. When he decided to publish these in book form, Winifred was invited to write the descriptive and ecological notes. The project was ambitious and time-consuming. Fresh flowering and fruiting material of the plants was required at regular intervals. Some came from Malahide Estate and other British gardens, but most species were collected in the wild in Tasmania, often in remote places, by dozens of local collectors who had been inspired by Lord Talbot's enthusiasm. Lord Talbot himself led several collecting forays. As the plants were collected, their identity was verified by Winifred or by the late Herbert J. King of Launceston, whose lists of Tasmanian endemics had first inspired Lord Talbot. Plants were then packed and sent by air to Heathrow, London, where they were collected by courier, delivered to Kew and painted by Margaret Stones. The paintings, and ultimately the proofs as well, were sent to Winifred for comment. The text was a similarly time-consuming task, as it needed to be short, scientifically accurate yet intelligible to the layman. Sadly, Lord Talbot died suddenly when only four volumes were completed but the work was seen to its conclusion by his sister, the Hon. Rose Talbot. The project proved to be a great success and increased interest in and knowledge of Tasmania's endemic plants. Subsequently the books have become much sought after by collectors.

In December 1966, after further periods as Acting Head of the Botany Department, Winifred retired and was appointed Honorary Research Fellow in Botany at the university. In the last ten years of her employment, she had been a Reader, one of the first two appointments in the university to this grade. These years had also seen the death of her mother in 1962 and a deterioration in the health of her father, whom she nursed at home. She opted for early retirement and continued work on the Students Flora.

After her father's death in 1967, Winifred submitted her published work to the University of London for a DSc degree; this was conferred in 1968. It was necessary for her to travel to London, her first return visit since 1950 , because the examiners reserve the right to call for an oral examination: in this instance it was not required. At one stage, she had considered returning to England to live at Kew, but she had now begun on the orchids for the Students Flora. Her determination to work from fresh material, so necessary in this plant group, delayed her return until eventually the spiralling cost of housing in London made the notion an impossibility. She continued travelling, however, and her most recent journeys were to the XII International Botanical Congress in Leningrad (1975), a visit to Iceland, and attendance at the XIII Congress in Sydney in 1981 .

In retirement, she maintained her close links with many amateur groups, gladly accompanying field excursions and helping with identifications. Whilst her formal teaching duties had ceased, she was always ready to help anyone with an interest in plants and a desire to learn, and is still regularly consulted by students, amateurs and professionals alike. Despite her dedication to botany, Winifred has always been concerned for the welfare of those around her. She has shown great kindness and generosity to those in need, although always in an unobtrusive way which has mostly passed unnoticed, except by those directly concerned.

As Winifred approaches her 85 th birthday, the final part of her Students Flora, a project begun more than 40 years previously, nears completion. However, there is no thought of stopping work and already she plans to revise some of the earlier volumes. Advancing years have naturally slowed her progress, but she remains as determined as ever. Honours in recognition of her achievements have come frequently in recent years and include the Royal Society of Tasmania Clive Lord Memorial Medal (1966), the Australian Natural History Medallion (1976), Membership of the Order of Australia (1977), an honorary DSc from the University of Tasmania (1987) and the SGAP Australian Plants Award (1988). Her botanical colleagues have named several plants in her honour: Epilobium curtisiae Raven, Richea curtisiae A. M. Gray, Viola hederacea spp. curtisiae L. Adams, Winifredia sola Johnson \& Briggs and Epacris curtisiae Jarman. She is renowned for her contributions not only to botanical research but to teaching in general and to the advancement of women in education. Throughout her life she has been deeply aware of the privileges of the educational opportunities she received, being of only the third generation of women in England to have the privilege of higher education. In turn, she has tried to pass on this awareness to others and has striven for fairness and equal opportunity. She has conducted her research without fanfare but with humility and a dedication to precision: in her view, her considerable achievements are simply a job that needed to be done and a foundation for others to build upon. 


\section{ACKNOWLEDGEMENTS}

I sincerely thank Dr Winifred Curtis for generously and patiently recounting her experiences. I also thank, Dr J. Jarman for editorial assistance, and $\mathrm{Mr}$ and Mrs C. Allan, Mrs M. Cameron, Mrs H. Craig, Mr and Mrs D. Morris, Mrs L. Murphy and Dr A. Orchard for helpful comments and suggestions.

\section{APPENDIX}

\section{Publications of Winifred Mary Curtis}

\section{BOOKS}

1948 Biology for Australian Students. Oxford University Press, Melbourne.

1952 Biology for Australian Students. 2nd edn. Oxford University Press, Melbourne.

1959 Biology for Australian Students. 3rd edn. Oxford University Press, Melbourne.

1962 Biology for Australian Students. 4th edn. Oxford University Press, Melbourne.

1956 The Student's Flora of Tasmania, Part 1. Govt Printer, Hobart.

1963 The Student's Flora of Tasmania, Part 2. Govt Printer, Hobart.

1967 The Student's Flora of Tasmania, Part 3. Govt Printer, Hobart.

1967 The Endemic Flora of Tasmania, Part 1. Text (paintings by Margaret Stones). The Ariel Press, London.

1969 The Endemic Flora of Tasmania, Part 2. Text (paintings by Margaret Stones). The Ariel Press, London.

1972 The Endemic Flora of Tasmania, Part 3. Text (paintings by Margaret Stones). The Ariel Press, London.

1973 The Endemic Flora of Tasmania, Part 4. Text (paintings by Margaret Stones). The Ariel Press, London.

1975 The Endemic Flora of Tasmania, Part 5. Text (paintings by Margaret Stones). The Ariel Press, London.

1978 The Endemic Flora of Tasmania, Part 6. Text (paintings by Margaret Stones). The Ariel Press, London.

1975 The Students Flora of Tasmania, Part 1. Revised edn (co-author D. I. Morris). Govt Printer, Hobart.

1980 The Students Flora of Tasmania, Part 4a. Govt Printer, Hobart.

\section{PUBLISHED PAPERS}

1931 Variation in the flowers of Lychnis dioica Unn. New Phytol. 30(1): 69-72.

1937 The Floral Morphology of Spartina townsendit. New Phytol. 36(1): 26-32.

1940 The structure and development of some apomicts of Taraxacum. Bull. Misc. Inf. (Royal Botanic Gardens, Kew) 1940(1): 1-29.

1941 Observations on the stem anatomy of the genus Richea. Pap. Proc. R. Soc. Tasm. (1940): 3335.

1944 Variations in Pultenaea juniperina Labill. Pap. Proc. R. Soc. Tasm. (1943): 197-199.

1947 Phyllachne colensoi Berggren, an addition to the list of sub-antarctic plants in the Tasmanian flora. Pap. Proc. R. Soc. Tasm. (1946): 31-33.

1948 Boomer Marsh - a preliminary botanical and historical survey (co-author J. Somerville). Pap. Proc. R. Soc. Tasm. (1947): 151-157.

1948 Biology in Education. Tasm. Educ. 3(2): 11-14.

1949 The Vegetation (of Tasmania) (co-author J. Somerville). Handbook of Tasmania, ANZAAS, Hobart 1949: 51-57.

1952 Variation in Certain Tasmanian Plants. New Phytol. 51(3): 398-414.

1952 The Vegetation (of Tasmania). Encyclopaedia Britannica. Vol.21, 14th edn (reprinted till 1969).

1953 A census of the Orchids of Tasmania. Pap. Proc. R. Soc. Tasm. (1952): 137-140.

1955 Recent records of Tasmanian flowering plants. Tasm. Nat. 2(3): 12-15.

1956 Australian flowering plants. Aust. Mus. Mag. 12 (4): 109-114.

1962 The Tasmanian Blue Gum (Floral Emblem for the State of Tasmania). Tasm. Govt Gaz. 13:700.

1963 The vegetation of Tasmania. The Brief Case (publ. Ronall, Hobart, for the Law Council of Tasmania): 29.

1963 Review: Schweinfurth, Ulrich. Studien zur Pflanzengeographie von Tasmanien (Bonner Geogr. Abhandlungen 31). J. Ecol. 51(2): 808809.

1964 The vegetation of Tasmania. In Walch's Tasmanian Almanac: 23-25.

1965 Forests and flowers of Mount Wellington Tasmania. Booklet, Tasmanian Museum and Art Gallery, Hobart.

1968 New combination in Celmisia. Taxon 17: 467.

1969 The vegetation of Tasmania. Tasm. Year Book 3: 55-59.

1969 New name in Epacris. Taxon 18: 244.

1970 Changes in nomenclature of two endemic Tasmanian plants. Vict. Nat. 87(9): 251. 
1972 Hooker, Sir Joseph Dalton (1817-1911). In Australian Dictionary of Biography, vol. 4: 416417.

1972 A new Tasmanian species of Milligania (family Liliaceae). Rec. Q. Vic. Mus. 45.
1974 Recent additions to the-Tasmanian flora and some notes on nomenclature (co-author D. I. Morris). Rec. Q. Vic. Mus. 50.

1984 New species of Tasmanian Monocotyledones in the families Juncaceae, Centrolepidaceae and Cyperaceae. Brunonia 7: 297-304.

G. Kantvilas

Tasmanian Herbarium, GPO Box 252C, Hobart, Tasmania, Australia 7001 